\title{
INCIDENCE OF DENGUE HEMORRHAGIC FEVER AFTER THE EARTHQUAKE IN CENTRAL SULAWESI INDONESIA
}

\author{
Meiske Elisabeth Koraag \\ National Institute of Health Research and Development Unit Donggala, Ministry of Health Indonesia
}

\begin{abstract}
The earthquake can cause a potential transmission of the disease after the disaster. One of the infectious diseases that could potentially be a post-earthquake outbreak is Dengue Hemorrhagic Fever (DHF). The earthquake, followed by a tsunami and liquefaction that struck Palu's city, Sigi's regency, and the regency of Donggala in Central Sulawesi in September 2018, led to the increased transmission of the dengue hemorrhagic fever disease in all three regions. This research aims to determine the incidence rate of DHF in the affected areas of the earthquake disaster in Central Sulawesi. The data used involved the number of DHF cases before and after the earthquake (20152019) in Palu, Sigi, and Donggala. The data was obtained from the Health Office of Central Sulawesi Province. The results of the analysis showed that the Incidence Rate (IR) of DHF in 2019 was 165.94 (Palu), 77.13 (Sigi), and 62.86 (Donggala). Dengue Hemorrhagic Fever's IR increased after the earthquake in Palu, Sigi, and Donggala in 2019 that marked the outbreak of DHF in all three regions. The highest increase in the DHF cases was found in Palu. The efforts to improve the health system are needed by strengthening DHF diagnosis, DHF case reporting, vector surveillance, active temephos distribution, and community empowerment to reduce DHF vector breeding sites.
\end{abstract}

Keywords: Earthquake, DHF, Outbreak

\section{Introduction}

Dengue fever had been an endemic disease in Palu, and the incidence of the disease potentially increased following the 2018 earthquake. This disease often causes extraordinary events/outbreaks (KLB) and has mainly become an outbreak in Palu. It had caused a concern that the number of dengue cases increased in Palu and other areas affected by the earthquake that triggered a tsunami and liquefaction in September 2018. The regency of Sigi and Donggala are among the areas that were also heavily affected by the earthquake, tsunami, and liquefaction.

Natural disasters can increase the likelihood of disease transmission, although they cannot cause a large-scale outbreak in the short-term. (Pan American Health, 2006) Disease transmission or an outbreak may occur several days, weeks, or months in the post-disaster or the recovery phase after a major disaster strikes. (Kouadio et al., 2012) Various aspects play a role in causing a post-disaster outbreak of diseases. These include the availability of clean water, sanitation facilities, the level of density, population health status, and healthcare services availability, all of which interact to influence the emergence of infectious diseases and mortality in the region. (Watson, Gayer, \& Connolly, 2007) For example, following the earthquake that generated the tsunami in Aceh in 2004, there was an increase in reported cases of clinically diagnosed tetanus in a month and later after the tsunami. (Aceh Epidemiology Group, 2006)

The earthquakes that caused tsunami and liquefaction can eliminate the existing mosquito breeding sites and form water puddles that become the new breeding habitats for mosquitoes. It may increase the vector population and the potential for disease transmission a few weeks following the disaster, depending on the vector species of local mosquitoes and preferable habitats. (Watson et al., 2007) The risk factors for the emergence of diseases caused by vectors such as dengue fever involve people mobility from the non-endemic to endemic areas, water 
puddles due to floods or water overflow, and high exposure proliferation of the disease vectors. (Kouadio et al., 2012)

Post-natural disaster redevelopment planning needs to take the prevention and control of environmental diseases into account, such as what happened after the earthquake in Padang. (Fanany, 2012) Post-disaster infection surveillance is necessary to anticipate an outbreak. After Haiti's earthquake in 2010, there was a surge in acute respiratory infections, acute watery diarrhea, and malaria or fever with unknown causes. (Polonsky et al., 2013) Poverty and population density are indirect factors in the emergence of dengue cases. The analysis shows that poverty and population density are significantly correlated with dengue hemorrhagic fever (DHF) in Indonesia. (Nuryunarsih, 2011)

The earthquake that occurred in Central Sulawesi on September 28, 2018, caused fatalities and damage to various infrastructures in Palu City, Sigi Regency, and Donggala Regency. The death toll is 2212, 965 are missing, 2537 are injured, and the number of refugees is 164,626. Damaged health facilities in Palu City 75.4\%, Sigi $51.5 \%$, and Donggala $95.9 \%$, all of which include severe, moderate, and minor damage. (Pemerintah Provinsi Sulawesi Tengah, 2018) In this situation, health problems began to arise after the disaster, one of which was increased transmission of diseases by vectors (mosquitoes), namely DHF. Residents have difficulty with water, so it holds water for a long time. Uncontrolled environmental conditions cause a lot of mosquito habitat (breeding place) in shelters/puddles around residential areas. This condition has the potential to increase the transmission of DHF disease in residents in earthquake-affected areas. The local government had to deal with two problems: fatalities and damage from earthquakes and public health problems after the disaster. When disasters hit, disease transmission risk factors increase, vector control activities are disrupted, and existing emergency plans were implemented. Disaster impact control activities should consider local conditions in disaster-affected areas. (Pan American Health Organization, 2013)

After the earthquake, the Central Sulawesi Provincial Health Office received reports on the number of DHF cases from all health facilities in Palu city, Sigi regency and Donggala regency. Data came from 27 health facilities in Palu City, 20 health facilities in Sigi Regency, and 20 health facilities in Donggala Regency during 2019. Health officials conduct epidemiological investigations in areas where DHF cases are present, spraying mosquito vectors (fogging focus) around the patient's residence.

This study aims to analyze the incidence of DHF in three regions hit by the earthquake, tsunami, and liquefaction, namely the city of Palu, Sigi's regency, and Donggala regency. Analyze DHF incidence patterns before and after an earthquake. Also, analyzing the potential for DHF outbreaks in all three earthquake-affected areas.

\section{Method}

This study used secondary data of the DHF collected from the Monthly Report of DHF of the Central Sulawesi Provincial Health Office. The data was obtained from the hospitals in Palu, Sigi's regency, and the regency of Donggala. The data collected involved the data cases of DHF in 2015-2019 in Palu, Sigi's regency, and the regency of Donggala. Diagnosis of DHF was confirmed by examining clinical symptoms and laboratory examinations (thrombocytopenia and hematocrit) in compliance with Indonesia's DHF management guidelines. Data collection was conducted using interviews with staff of DHF program management at the Central Sulawesi Provincial Health Office. All variables were analyzed quantitatively using descriptive statistics. The number of DHF cases in 2015-2019 is presented in a bar chart. Characteristics of respondents including age and gender presented in a table, variables were analyzed using SPSS version 15. The formula for calculating the incidence rate and case fatality rate of $\mathrm{DHF}(\mathrm{CDC}, 2012)$ : 


$$
\begin{aligned}
& \text { Incidence Rate }=\frac{\text { Number of New Cases of Diseases }}{\text { Size of Population at Start of Population }} \times 100.000 \\
& \text { Case Fatality Rate }=\frac{\text { Number of Cause-Specific Deaths Among the Incident Cases }}{\text { Total Number of Incident Cases }} \times 100 \%
\end{aligned}
$$

\section{Result}

The results showed an increase in the number of dengue cases in Palu, Sigi's regency, and the regency of Donggala after the earthquake that hit the three regions on 28 September 2018. The number of dengue cases in the three areas started to rise in January 2019, three months after the earthquake.

In Palu, the dengue cases' increase was relatively high in early 2019, from January to February, and the number of cases went down from March to April. However, it rose again in May and July and began to decline the subsequent month until December (Figure 1). The dengue cases in early 2019 were higher than the number of dengue cases in early 2018 and 2017. The number of dengue cases in Palu from 2015 to 2018 decreased but grew again in 2019.

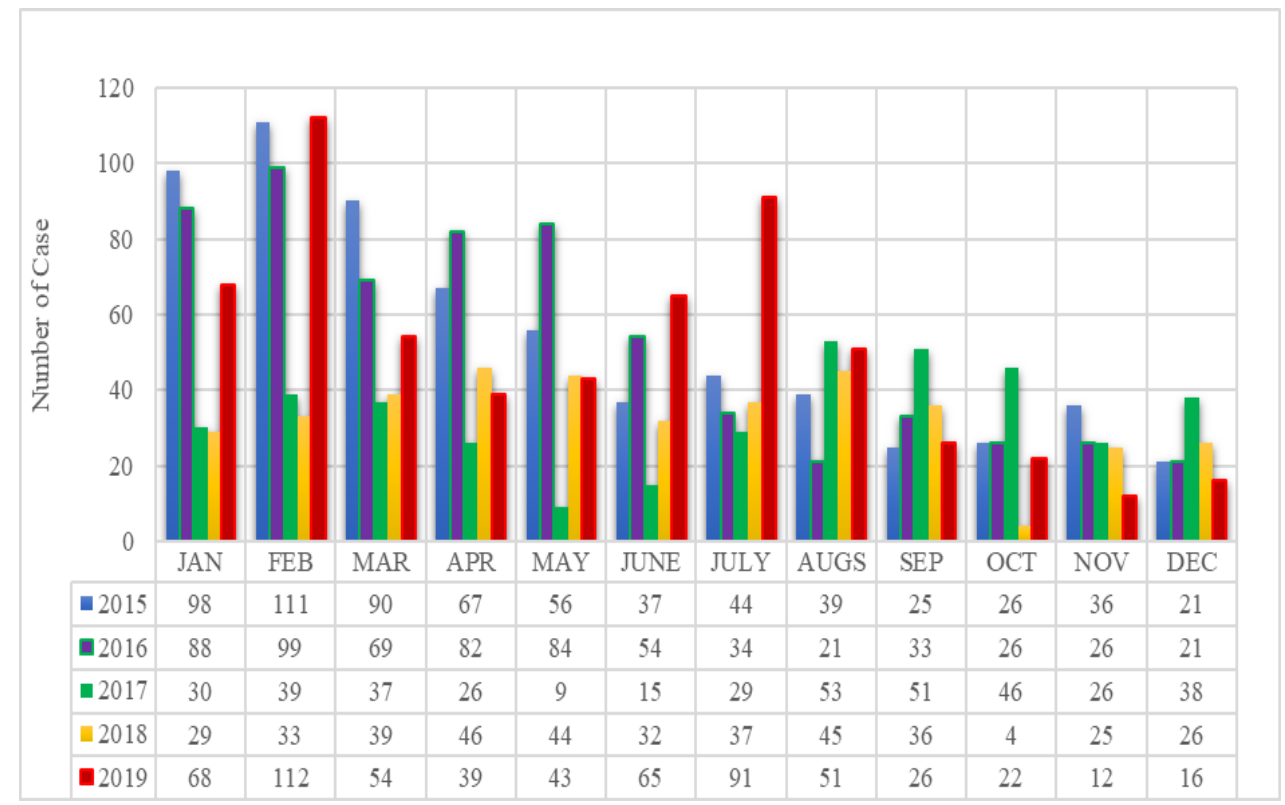

Figure 1. Incidence of DHF in Palu City 2015-2019 


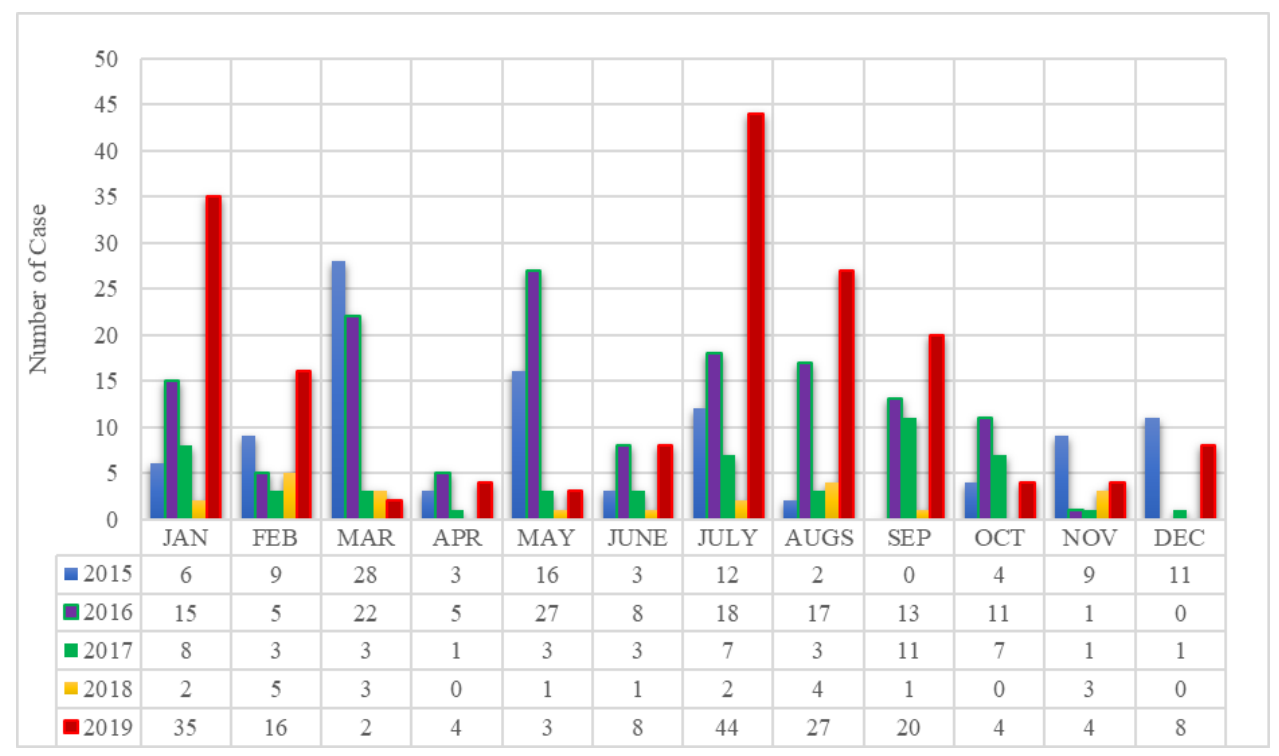

Figure 2. Incidence of DHF in Sigi Regency 2015-2019

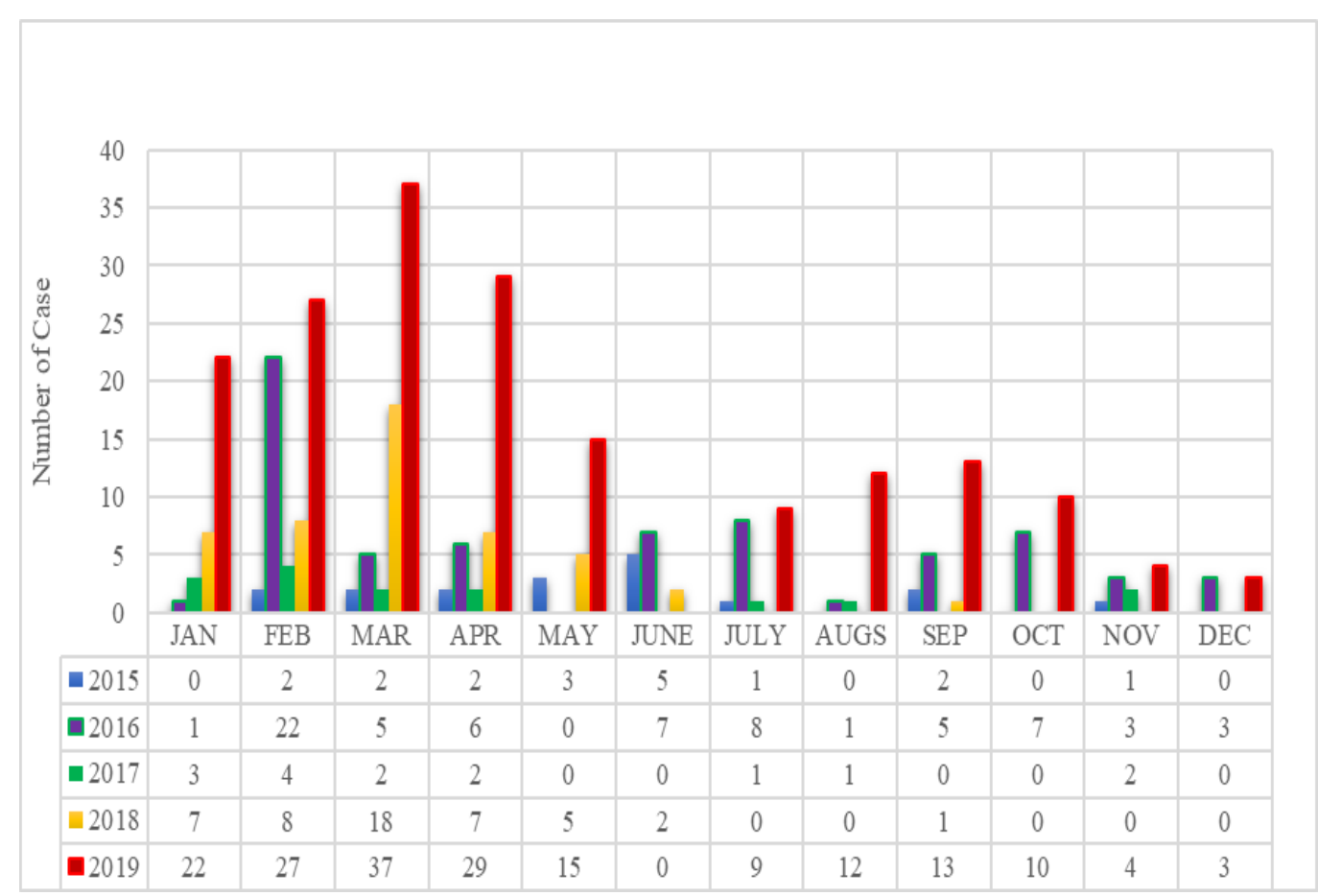

Figure 3. Incidence of DHF in Donggala Regency 2015-2019

Meanwhile, the number of DHF cases in Sigi's regency decreased from 2015 to 2018 and increased again in 2019 (Figure 2). The number of dengue cases in 2018 showed a decreasing pattern even though it rose at the beginning of the year. Unlike usual in 2019, the number of dengue cases at the beginning of the year, in January, increased sharply and decreased until May. However, there was a high increase in July and decreased again from August to December. In general, the number of dengue cases in 2019 showed an increase from the previous years; a very dramatic increase occurred in January and July 2019.

The number of DHF cases in the regency of Donggala shows a fluctuating pattern from 2015 to 2018 and experienced a very high increase in 2019 (Figure 3). In 2018, the number of dengue cases went up from January to March but declined from April to December. The number of DHF cases in 2019 rose very sharply compared 
to the previous years, especially from January to March. Then, from April to June, the number of cases came down again but increased again from July to September, and decreased again in number from October to December. In general, there was a high increase in dengue cases in 2019, around three times higher than in 2018.

Of the three areas affected by the earthquake in Central Sulawesi, the city of Palu had the highest number of DHF cases compared to the two other areas affected by the earthquake in Central Sulawesi (Table 1). After the earthquake (2019), the IR value in the city of Palu was 165.9 cases in every 100,000 population (total population 360,973 ), in the regency of Sigi was 77.1 cases in every 100,000 people (total population 226,876), and the regency of Donggala was 62.9 cases in every 100,000 people (total population 287,921). Most of the cases in Palu were found in those aged 15-44 years (47.7\%). Meanwhile, most of the cases in Sigi were found in those aged 15-44 years old (56\%), and the majority of DHF cases in Donggala were found in youths aged 5-14 years old $(49.2 \%)$. In terms of gender, most of the DHF cases were found among males, $52.4 \%$ in Palu, $57.7 \%$ in Sigi, and 51.4\% in Donggala. Most DHF cases in Palu City and Sigi Regency are men aged 15-44 years, while DHF cases in Donggala regency are mostly men aged 5-14 years.

The number of deaths due to DHF in the city of Palu is also the highest. The death cases from DHF mostly occurred in Palu, with 9 cases dengan nilai CFR 1.5. Most of the cases that died were aged 5-14 years $(\mathrm{CFR}=$ 0.8). Most of the cases that died were women aged 5-14 years (Table 2).

Table 1. Number of cases by DHF (by age and gender) in Central Sulawesi 2019

\begin{tabular}{|c|c|c|c|c|c|c|c|c|c|}
\hline \multirow{3}{*}{$\begin{array}{l}\text { Age } \\
\text { group }\end{array}$} & \multicolumn{9}{|l|}{ Cases } \\
\hline & \multicolumn{3}{|c|}{ Palu City } & \multicolumn{3}{|c|}{ Sigi Regency } & \multicolumn{3}{|c|}{ Donggala Regency } \\
\hline & Male & Female & Total & Male & Female & Total & Male & Female & Total \\
\hline$<5$ & 37 & 49 & 86 & 5 & 3 & 8 & 34 & 34 & 68 \\
\hline $5-14$ & 96 & 79 & 175 & 26 & 13 & 39 & 46 & 43 & 89 \\
\hline $15-44$ & 160 & 126 & 286 & 54 & 44 & 98 & 10 & 6 & 16 \\
\hline$>44$ & 21 & 31 & 52 & 16 & 14 & 30 & 3 & 5 & 8 \\
\hline Total & 314 & 285 & $\begin{array}{l}599 \\
(165.9)\end{array}$ & 101 & 74 & $\begin{array}{c}175 \\
(77.1)\end{array}$ & 93 & 88 & $\begin{array}{l}181 \\
(62.9)\end{array}$ \\
\hline
\end{tabular}

Table 2. Number of deaths by DHF (by age and gender) in Central Sulawesi 2019

\begin{tabular}{|c|c|c|c|c|c|c|c|c|c|}
\hline \multirow{3}{*}{$\begin{array}{l}\text { Age } \\
\text { group }\end{array}$} & \multicolumn{9}{|c|}{ Deaths } \\
\hline & \multicolumn{3}{|c|}{ Palu City } & \multicolumn{3}{|c|}{ Sigi Regency } & \multicolumn{3}{|c|}{ Donggala Regency } \\
\hline & Male & Female & $\begin{array}{l}\text { Total } \\
\text { (CFR) }\end{array}$ & Male & Female & $\begin{array}{l}\text { Total } \\
\text { (CFR) }\end{array}$ & Male & Female & $\begin{array}{l}\text { Total } \\
\text { (CFR) }\end{array}$ \\
\hline$<5$ & 1 & 2 & $\begin{array}{l}3 \\
(0.5)\end{array}$ & 0 & 0 & 0 & 1 & 0 & $\begin{array}{l}1 \\
(0.5)\end{array}$ \\
\hline $5-14$ & 2 & 3 & $\begin{array}{l}5 \\
(0.8)\end{array}$ & 0 & 0 & 0 & 1 & 0 & $\begin{array}{l}1 \\
(0.5)\end{array}$ \\
\hline
\end{tabular}




\begin{tabular}{llllllllll}
\hline $15-44$ & 1 & 0 & $\begin{array}{l}1 \\
(0.2)\end{array}$ & 0 & 0 & 0 & 0 & 0 & 0 \\
\hline$>44$ & 0 & 0 & 0 & 0 & 0 & 0 & 0 & 0 & 0 \\
\hline Total & 4 & 5 & 9 & 0 & 0 & 0 & 2 & 0 & 2 \\
& & & $(1.5)$ & & & & & & $(1.1)$ \\
\hline
\end{tabular}

\section{Discussion}

The natural disaster of the earthquake that caused tsunami and liquefaction in Palu's city, Sigi's regency, and the regency of Donggala brought about health problems in the three regions. The issues included a higher number of disease transmission after the disaster than the usual conditions, DHF. The incidence of the disease rose in the three areas in 2019 due to the natural disaster. It increased three times from the previous year. The incidence rate of the DHF cases in the three regions after the earthquake was relatively high and exceeded the national IR target for DHF, 49 cases every 100,000. The number of DHF cases was obtained from the Central Sulawesi Provincial Health Office, from hospital reports from the three regions. Most cases of DHF were found in adults and children (productive age), and only a small number of the cases were found in the older adults/pre-elderly.

Palu's city has the highest number of DHF cases than the other two regencies in Central Sulawesi. It had even happened several years before the earthquake hit the three regions. The population density of Palu is 940 people/km2 (in 2020)(BPS Kota Palu, 2020), while the regency of Donggala has a population density of 58 people/km2 (in 2020)(BPS Kabupaten Donggala, 2020), and the regency of Sigi has 46 people/km2 (in 2020)(BPS Kabupaten Sigi, 2020). The population density of the city of Palu is higher than the other two regencies. It also contributes to the existence of the DHF vector habitats, where the potential for the DHF vector habitats in Palu's city is higher than the other two districts. Most cases of DHF are in the city of Palu, Sigi Regency, and Donggala Regency and are in the adult and productive age group. It is possible that the higher mobility factor in younger people also has an impact on this phenomenon.

Several problems lead to the increase in the DHF cases in Palu, Sigi's regency, and the regency of Donggala. First, the increase in DHF cases in the three areas was caused by the emergence of many breeding sites for Aedes as a DHF vector after the tsunami and liquefaction. Based on a survey conducted by the National Institute of Health Research and Development Unit Donggala, many Aedes mosquito larvae were found on unused tires in areas affected by liquefaction in Palu. (Balai Litbangkes Donggala, 2019) Also, many garbage such as cans and plastics were found, which potentially becomes a new container habitat for DHF vector mosquitoes to breed. Vector control activities were conducted after the disaster by the local government, such as through air spraying of disinfectant and fogging. However, DHF vector surveillance has not been carried out, including the administration of temephos that has not been reported. Many DHF cases were also unreported properly because the people in the regions did not have access to the health services (hospitals) and over-diagnosis by the officers. The readiness and ability of health workers to diagnose patients properly will result in better recognition of dengue infection in health facilities. Adherence to dengue management guidelines in Indonesia will help reduce the incidence and mortality rates of DHF. (Karyanti \& Hadinegoro, 2016)

The increase in the DHF cases is also caused by changing seasons/weather. When it comes to the rainy season and the dry/hot season, the DHF cases usually increase. In general, the city of Palu, Sigi's regency, and the regency of Donggala only have two seasons, the dry season and the rainy season. Based on the Meteorological, Climatological, and Geophysical Agency (BMKG) in 2019, the average rainfall intensity each month throughout the year in Palu is relatively low (less than $100 \mathrm{~mm}$ ). (Badan Meteorologi, Klimatologi, 2020) The low intensity of rainfall almost occurs every month even though there is an increase in rainfall in March and June. The average rainfall in Sigi and Donggala is still classified as low even though there is an increase in rainfall in March and June. Other evidence was found in previous research in Jember that in 2008 the peak of the DHF 
outbreak occurred during the rainy season in November to February. It means that the DHF cases are influenced by climate/season. (Nurdian \& Lelono, 2008)

\section{Conclusion}

The DHF outbreak in Palu, Sigi's regency, and the regency of Donggala occurred after the earthquake that caused a tsunami and liquefaction. It implies that the local governments need to make efforts to improve the health system in the regions affected by the earthquake, including strengthening diagnostic capacities on DHF among the hospital officers and a reporting system for the DHF cases, surveillance of DHF vector, and active distribution of temephos, and community empowerment to reduce the DHF vector breeding sites in the home environment and public places.

\section{Acknowledgment}

I want to thank Mr. Muhadi as a staff of the Central Sulawesi Provincial Health Office who helped provide the DHF data and discussions about the DHF control program in Central Sulawesi. I also would like to show our gratitude to the National Institute of Health Research and Development of the Ministry of Health Indonesia for providing financial support for this study's report.

\section{Conflict of Interest}

The author declares no conflict of interest

\section{Reference}

Aceh Epidemiology Group. (2006). Outbreak of tetanus cases following the tsunami in Aceh province , Indonesia. Global Public Health, 1(2), 173-177. https://doi.org/10.1080/17441690600652803

Badan Meteorologi, Klimatologi, dan G. (BMKG) I. (2020). Data Online Pusat Database BMKG (Data Iklim Harian). Retrieved from http://dataonline.bmkg.go.id/dashboard_user

Balai Litbangkes Donggala. (2019). Laporan Survei Jentik di Kota Palu. Donggala Indonesia: Balai Litbangkes Donggala.

BPS Kabupaten Donggala. (2020). Kabupaten Donggala Dalam Angka (Donggala Regency in Figures 2020) (1st ed.). Donggala Indonesia: BPS Kabupaten Donggala.

BPS Kabupaten Sigi. (2020). Kabupaten Sigi Dalam Angka (Sigi Regency in Figure 2020) (1st ed.). Sigi Indonesia: BPS Kabupaten Sigi.

BPS Kota Palu. (2020). Kota Palu Dalam Angka Tahun 2020 (1st ed.). Palu Indonesia: BPS Kota Palu.

CDC. (2012). Principles of Epidemiology in Public Health Practice. Centers for Disease Control and Prevention (CDC) (Third). Atlanta USA: U.S. Departement of Health And Human Services Centers for Disease Control and Prevention (CDC). https://doi.org/10.1201/9781315381848

Fanany, D. (2012). Dengue Hemorrhagic Fever and Natural Disaster: The Case of Padang, West Sumatra. International Journal of Collaborative Research on Internal Medicine \& Public Health, 4(5), 673-678. Retrieved from https://internalmedicine.imedpub.com/abstract/dengue-hemorrhagic-fever-and-natural-disaster-the-case-ofpadang-west-sumatra-6163.html

Karyanti, M. R., \& Hadinegoro, S. R. (2016). Perubahan Epidemiologi Demam Berdarah Dengue Di Indonesia. Sari Pediatri, 10(6), 424. https://doi.org/10.14238/sp10.6.2009.424-32

Kouadio, I. K., Aljunid, S., Kamigaki, T., Hammad, K., \& Oshitani, H. (2012). prevention and control measures Infectious diseases following natural disasters : prevention and control measures. Expert Rev. Anti Infect. Ther, 10(1), 95-104. https://doi.org/10.1586/eri.11.155 
Nurdian, Y., \& Lelono, A. (2008). Prediction of Distribution Patterns of Aedes Aegypti As Dhf Main Vector In Jember. Folia Medica Indonesiana, 44(1), 11-14. Retrieved from http://journal.unair.ac.id/FMI@ prediction-ofdistribution-pattern-of-aedes-aegypti-as-dhf-main-vector-in-jember-article-2500-media-3-category-3.html

Nuryunarsih, D. (2011). Sociodemographic Factors to Dengue Hemmorrhagic Fever Case in Indonesia. Jurnal Kesehatan Masyarakat Nasional, 10(1), 10-16. Retrieved from https://media.neliti.com/media/publications/39920-EN-sociodemographic-factors-to-dengue-hemmorrhagicfever-case-in-indonesia.pdf

Pan American Health, O. (2006). Bencana Alam Perlindungan Kesehatan Masyarakat. Jakarta: Penerbit Buku Kedokteran EGC.

Pan American Health Organization. (2013). Vector Control in Disaster Situations. Retrieved February 14, 2021, from https://www.paho.org/disasters/index.php?option=com_content\&view=article\&id=541:vector-control-indisaster-situations \&Itemid=1169\&lang=en

Pemerintah Provinsi Sulawesi Tengah. (2018). Laporan Finalisasi Data dan Informasi Bencana Gempa Bumi , Tsunami dan Likuifaksi di Sulawesi Tengah Per Tanggal 20 Des 2018. Palu: Pemerintah Provinsi Sulawesi Tengah. Retrieved from https://www.humanitarianresponse.info/sites/www.humanitarianresponse.info/files/documents/files/lap_ke_gub _20_des_2018.pdf

Polonsky, J., Luquero, F., Francois, G., Rousseau, C., Caleo, G., Ciglenecki, I., ... Checchi, F. (2013). Public Health Surveillance After the 2010 Haiti Earthquake: the Experience of Médecins Sans Frontières. PLoS $\begin{array}{lll}\text { Currents, } & 7(5), & 1-19 .\end{array}$ https://doi.org/https://dx.doi.org/10.1371\%2Fcurrents.dis.6aec18e84816c055b8c2a06456811c7a

Watson, J. T., Gayer, M., \& Connolly, M. A. (2007). Epidemics after Natural Disasters. Emerging Infectious Diseases, 13(1), 1-5. Retrieved from https://www.ncbi.nlm.nih.gov/pmc/articles/PMC2725828/ 